\title{
EVALUATION OF STANDARD REAGENTS FOR RADIAL-IMMUNODIFFUSION ASSAYS. IN VITRO CONTROL OF RABIES VACCINES
}

\author{
Graciela S. MICELI(1), Jorge TORROBA(2), Walter TORRES(2), Jorge ESTEVES MADERO(3) \& Ana Maria DÍAZ(2)
}

\begin{abstract}
SUMMARY
The RID assay is one of the in vitro methods used for in-process control in the production of rabies vaccines for veterinary use. It has been shown to be very useful for determining antigen concentration in the final bulk product. The work presented in this paper, including the production and standardization of candidate standard reagents for use in the Radial Immunodiffusion Assay (RID) was carried out at the Pan American Institute for Food Protection and Zoonoses (INPPAZ/PAHO/WHO). The study was completed with the cooperation of the Faculty of Veterinary Sciences, National University of La Plata (NULP), Argentina, where the validation of the proposed standards and the quality control of samples from 28 different batches of rabies vaccines produced with Pasteur strain rabies virus (PV) in BHK cells were performed. The activity of the vaccines was determined by in vivo (NIH) and in vitro (RID)assays. The results of the candidate reagents for the reagent standardization tests showed stability, sensitivity and reproducibility. The Relative Potency the 1.2 between the problem vaccines and the reference vaccine was estimated by variance and regression analysis. The results of our validation study show that the INPPAZ (PAHO/WHO) is capable of producing and distributing the above-mentioned standard reagents, as well as of providing support for the incorporation of the RID technique (sensitive, rapid and inexpensive) to the laboratories that manufacture rabies vaccines in Latin America and the Caribbean.
\end{abstract}

KEYWORDS: Rabies vaccines; In vitro control; Immunodiffusion.

\section{INTRODUCTION}

During the past years, in vitro tests for the process control of biological products ${ }^{13}$ such as rabies vaccines and sera have been developed and applied world-wide for the purpose of providing manufacturers with preliminary data on the future quality of the finished product. Such methods include the antigen-antibody binding test ${ }^{1,2}$, the enzyme immunoassay ${ }^{23}$ and the counterimmunoelectrophoresis technique ${ }^{4,5,16}$.

In 1975 and 1977 the radial immunodiffusion test (RID) was used for determining inactivated antigens in vaccines against the influenza virus (SCHILD et al.,1975'17; WOOD et al.,197726) and the poliovirus (SCHILD et al., 1980) ${ }^{18}$. FERGUSON \& SCHILD $^{7}$, FERGUSON et $a l .^{8,9,10}$ and FITZGERALD \& NEEDY ${ }^{12}$ were the first to use this method for the assay of rabies vaccines.

The RID test ${ }^{13,14,15}$ is rapid, easy to perform and sensitive; it requires the use of reagents of proven quality and stability.The purpose of this collaborative study between the INPPAZ (PAHO/WHO) and the Faculty of Veterinary Sciences (NULP), Argentina was to evaluate the quality of the standard reagents (reference vaccines and reference sera) in order to determine the antigen concentration in cell-culture vaccines produced in Latin America and the Caribbean.

\section{MATERIALS AND METHODS}

\section{Standard Serum}

\subsection{Polyclonal Hyperimmune Serum}

PV virus was purified with aluminum phosphate according to the procedure described by SCHNEIDER ${ }^{19}$, inactivated with Betapropiolactone and adsorbed in Freund's complete adjuvant. Two rabbits were inoculated by the intramuscular (IM) route with six doses of PV-BHK rabies vaccine, each of $0.5 \mathrm{ml}$ administered every three days. Antibody titers were controlled by counterimmunoelectrophoresis (CIE) and seroneutralization ( $\mathrm{SN}$ ) in mice. A booster dose of $0.8 \mathrm{ml}$ of purified PV virus was administered as follows: $0.1 \mathrm{ml}$ intradermically (ID), 0.2 $\mathrm{ml}$ subcutaneously (SC) and $0.5 \mathrm{ml} \mathrm{IM}$.

Blood for the tests was obtained from the marginal vein of the ear, and antibody titers were determined by CIE and SN. The final bleeding was performed when the rabbits showed titers higher than 1:1500 by CIE and 1:5000 by SN.

\footnotetext{
(1) Faculty of Veterinary Sciences, National University of La Plata, Cathedra Immunology, 60 y 118, CP 1900, La Plata, Province Buenos Aires, Argentina

(2) Pan American Institute for Food Protection and Zoonoses, (INPPAZ/PAHO/WHO), Martinez, Argentina

(3) National Service of Animal Health (SENASA), Argentina.
} 
The serum was separated, inactivated, and distributed into ampoules in $0.5 \mathrm{ml}$ aliquots. Fifty per cent of the ampoules were stored frozen and $50 \%$, lyophilized. Neutralizing rabies antibodies were determined in the final batch.

\subsection{PV-BHK antiglycoprotein and antiribonucleoprotein sera}

The PV-BHK virus was treated with detergent and ultracentrifugation $^{3,21}$ to separate the glycoprotein and ribonucleoprotein fractions. These antigens were used for the booster inoculation of the rabbits previously immunized with PV-BHK vaccine in the manner described above for the hyperimmune polyclonal serum.

\subsection{Standardization of the Polylonal Hyperimmune Serum}

$1 \%$ agarose in saline buffered solution (SBS) was prepared in four immunoplates containing respectively $50 \mu \mathrm{l}, 100 \mu \mathrm{l}, 150 \mu \mathrm{l}$ and $250 \mu \mathrm{l}$ of polyclonal hyperimmune serum. The plates were stored at $4{ }^{\circ} \mathrm{C}$ for 10 minutes. In each, four wells $4 \mathrm{~mm}$ in diameter were cut in two parallel lines. The agarose was removed and four dilutions series $(1: 2,1: 4,1: 8$, 1:16) of the International Reference Vaccine were distributed in duplicate in the amount of $20 \mu \mathrm{l}$ per well. The RID technique was performed as described in paragraph 5 below.

The linear regression parameters for the relations were determined: $\log 10$ of the dilutions of the International Reference Vaccine (axis $\mathrm{x}$ ) versus the measurements of the diameters of the precipitation zones (axis y).

\section{Homologous Reference Vaccine}

A batch of PV-BHK vaccine (homologous to the problem vaccines), inactivated with Betapropiolactone without adjuvant ${ }^{6}$ was prepared and standardized against the National Standard Vaccine by the $\mathrm{NIH}^{20}$ potency test. The Reference Vaccine showed Activity: $1 \mathrm{IU} / \mathrm{ml}$ and average 50\% effective dose: 1:69 +/- 3 Standard Deviation (SD) Interval 1:49-1:100. It was distributed in $0.5 \mathrm{ml}$ flasks and stored at $-70{ }^{\circ} \mathrm{C}$.

Five samples of the homologous Reference Vaccine were collected at random. Five independent tests were performed to standardize the vaccine.

\subsection{RID Standardization of the Homologous Reference Vaccine}

One percent agarose in SBS was prepared in one immunoplate with a $250 \mu \mathrm{l}$ volume of Polyclonal Standardized Hyperimmune Serum as described in paragraph 1.3 . The plate was stored at $4{ }^{\circ} \mathrm{C}$ for 10 minutes and eight parallel wells $4 \mathrm{~mm}$ in diameter were punched. The four series dilutions $(1: 2,1: 4,1: 8,1: 16)$ of the Homologous Reference Vaccine were inoculated in duplicate. The RID technique was carried out as described in paragraph 3 below. The results were assayed following the same procedure as in the case of the standardization of the hyperimmune serum.

\section{Problem Vaccines}

Samples from twenty-eight batches of vaccines were controlled to assess the sensitivity and specificity of the reagents. All the vaccines were produced in BHK cells with PV rabies virus and no adjuvant. The standard production technique was used with a 1 to $2 \%$ bovine fetal serum in the final product. All the batches originated from laboratories in Latin America and the Caribbean.

The activity of the vaccines was determined by the standard potency $\mathrm{NIH}$ test and ranged between 0.3 and $7.3 \mathrm{IU} / \mathrm{ml}$.

\section{Radial Immunodiffusion Technique}

Procedure

$200 \mu \mathrm{l}$ of each of the problem vaccines and of the Homologous Reference Vaccine were treated with $20 \mu \mathrm{l}$ of detergent (Emulphogene BC 720 at $20 \%$ in SBS) and were allowed to react for 30 minutes at room temperature.

One per cent agarose in SBS was prepared in immunoplates with the optimum amount of the hyperimmune rabies serum: 1:250 (paragraph 1.3). Series dilutions of the problem vaccines were prepared in SBS at a ratio of 1:2, and inoculated in duplicate at a volume of $20 \mu \mathrm{l}$ per well. They were allowed to diffuse for 24 hours at room temperature in a humid chamber following which they were stored at $35^{\circ} \mathrm{C}$ for $18-24$ hours in a container with SBS pH 7.2. They were then washed, dried on Gel Bond hydrophilic paper, stained with Coomassie blue stain R-250 and left to dry at room temperature. The diameters of the precipitation areas were measured with a millimetric ruler with a probable error of $0.5 \mathrm{~mm}$.

\section{Calculations}

Relative potency (RP)

The relative potency is defined as the quotient between the dose of the reference preparations $(\mathrm{Xr})$ and that of the test preparations $(\mathrm{Xp})$. Both give a specific response against the reference serum in the RID system.

To determine the RP measurements were made of the diameters of the precipitation zone of each problem vaccine and compared with those of the homologous Reference Vaccine (y), versus the log of the dose (x). The relative potency is obtained from the horizontal distance between both parallel lines as follows:

$$
\text { Antilog } M=\left[X r-X p-\frac{(Y r-Y p)}{b}\right]
$$

Variance and regression analyses were carried out to determine whether the RID tests complied with the regression, linearity, parallelism, and homogeneity of variances ${ }^{11,22}$.

\section{RESULTS AND CONCLUSIONS}

Table 1 shows the linear regression parameters and correlation coefficients obtained when immunoplates were prepared with different concentrations of the Polyclonal Hyperimmune Serum. The sensitivity of the plates was seen to be comparable. It was observed that all the correlation coefficients with the different volumes of serum were close to the unit. The $250 \mu \mathrm{l}$ volume was selected because it produced sharper 
Table 1

Standardization of the Polyclonal Hyperimmune serum

\begin{tabular}{|c|c|c|c|c|c|c|c|}
\hline \multirow{2}{*}{$\begin{array}{l}\text { Plate } \\
\mathrm{N}^{\mathrm{o}}\end{array}$} & \multirow{2}{*}{$\begin{array}{l}\text { Serum } \\
\text { Anti-PV } \\
\mu \mathrm{l}\end{array}$} & \multicolumn{4}{|c|}{$\begin{array}{c}\text { Diameters of the precipitation zones } \\
\text { vs } \\
\text { Dilution of the ReferenceVaccine }\end{array}$} & \multicolumn{2}{|c|}{ Linear Regression } \\
\hline & & $1: 2$ & $1: 4$ & $1: 8$ & $1: 16$ & $(a+b \cdot x)$ & $\mathrm{r}^{*}$ \\
\hline 1 & $100 \mu \mathrm{l}$ & 16 & 15 & 13 & 10 & $18.5-6.66 \mathrm{x}$ & -0.97 \\
\hline 2 & $100 \mu \mathrm{l}$ & 16 & 15 & 13 & 12 & $17.5-4.66 \mathrm{x}$ & -0.98 \\
\hline 3 & $150 \mu \mathrm{l}$ & 14 & 13 & 11 & 8 & $16.5-6.66 x$ & -0.97 \\
\hline 4 & $150 \mu \mathrm{l}$ & 14 & 13 & 11 & 10 & $15.5-4.66 \mathrm{x}$ & -0.98 \\
\hline 5 & $250 \mu \mathrm{l}$ & 14 & 12 & 10 & 9 & $15.5-5.66 x$ & -0.99 \\
\hline 6 & $250 \mu \mathrm{l}$ & 14 & 12 & 10 & 8 & $16-6.66 x$ & -1 \\
\hline
\end{tabular}

Table 2

Results of the RID tests of samples obtained from 28 batches of rabies vaccines

\begin{tabular}{ccccc}
\hline \multicolumn{2}{c}{ Samples } & RID Test & \multicolumn{2}{c}{ NIH Test } \\
$\mathrm{N}$ & $\%$ & $(\mathrm{RP})$ & ED50-A & UI/ml-A \\
\hline 15 & 54 & 1.5 & $1: 100$ & 1.0 \\
3 & 11 & 1.2 & $1: 84$ & 0.9 \\
8 & 32 & 0.6 & $1: 47$ & 0.6 \\
2 & $\mathrm{NC}$ & $\mathrm{NC}$ & $<1: 5$ & $\mathrm{NC}$ \\
\hline
\end{tabular}

ED50-A: 50\% Effective Dose - Average; IU/ml-A: International Units Average; NC: Non-calculable

precipitation zones and because the correlation coefficient value was $r=-1.0$. No precipitation zones were observed with $50 \mu \mathrm{l}$ of serum and therefore this concentration does not appear in the table.

The results of the assessment of the Homologous Reference Vaccine were obtained on five samples of the final batch in the same number of independent RID tests. The variance analysis was performed and the vaccine dilutions were expressed as $\log 2$, and the diameters of the precipitation zones were given in millimeters. The results of the tests did not show statistically significant differences. The diffusion diameters of the Homologous Reference Vaccine ranged between $17 \mathrm{~mm}$ for the lowest dilution and $11 \mathrm{~mm}$ for the highest.

It may be concluded that the dose-response relationship with both candidate standard reagents, i.e., the Polyclonal Hyperimmune Serum and the Homologous Reference Vaccine, was satisfactory.The results of the RID testing of samples from 28 different batches of PV-BHK rabies vaccines are presented in Table 2.

At the laboratories of the INPPAZ (PAHO/WHO) and of the Faculty of Veterinary Sciences, PV-BHK rabies vaccines with a 1.2 or higher RP complied with the Minimum 1.0 IU/ml Potency Requirement in the in vivo $\mathrm{NIH}$ test, as recommended by the World Health Organization (WHO) for vaccines for veterinary use $^{24}$.
The RID test was capable of discriminating Relative Potency values ranging between 0.6 and 1.5 , equivalent to $0.6 \mathrm{IU} / \mathrm{ml}$ and $1.0 \mathrm{IU} / \mathrm{ml}$ in the NIH test, respectively.

It may be concluded that:

a) The reference reagents produced by the INPPAZ (PAHO/WHO) may be used as standard reagents for the implementation of the RID technique for in-process control during the manufacture of PV-BHK rabies vaccines for veterinary use.

b) It is essential that each laboratory producing rabies vaccines should determine by using the RID technique, its minimum RP required to comply with the Minimum Requirements of the in vivo Potency test (NIH) of the final product, on the basis of the reproducibility of the quality of its products (consistency).

\section{RESUMO}

\section{Avaliação de reativos padrões para provas de Imunodifusão Radial. Controle in vitro de vacinas antirrábicas}

A prova de Imunodifusão Radial (IDR) é um método in vitro conveniente para determinar a concentração de antígenos no produto final como um todo, de vacinas anti-rábicas para uso veterinário. Os reativos padrões candidatos para uso na prova IDR, proposta para o controle de processo de vacinas de cultivo celular, elaboradas na América Latina e Caribe, foram produzidos e padronizados no Instituto Panamericano de Proteção de Alimentos e Zoonoses (INPPAZ). A validação dos padrões e o controle de qualidade de 28 lotes de vacinas anti-rábicas, de diferentes procedências, foram realizados na Faculdade de Ciências Veterinárias da Universidade de La Plata, Argentina (UNLP). Todas as vacinas foram elaboradas com virus rábico cepa Pasteur (PV) em células BHK e sua atividade foi determinada através de provas in vivo (NIH) e in vitro (IDR).

Os resultados dos reativos, candidatos para as provas de padronização, demonstraram estabilidade, sensibilidade e reprodutibilidade.

Por análise de variância e de regressão foi estimada a potência relativa de 1.2 entre as vacinas problemas e a vacina de referência. 
Os resultados deste estudo de validação indicam que o INPPAZ, está em condições de elaborar e distribuir os reativos padrões acima mencionados e apoiar a adoção da técnica de IDR (sensível, rápida, econômica) pelos laboratórios de produção de vacinas anti-rábicas da América Latina e Caribe.

\section{ACKNOWLEDGEMENTS}

Appreciation is expressed to Dr Lieven Uytterhaegen for his permanent support to the study, to Mrs Nelly Bonomini for the paper translation and to Mr Daniel Freyre for his technical assistance.

\section{REFERENCES}

1. ARKO, R.J.; WIKTOR, T.J. \& SIKES, R.K. - The antibody binding test for vaccine potency. In: KAPLAN, M.M. \& KOPROWSKI, H., ed. Laboratory techniques in rabies. 3.ed. Geneva, WHO, 1973. p. 292-294.

2. BARTH, R.; GROSS-ALBENHAUSEN, E.; JAEGER, O. \& MILCKE, L. - The antibodybinding test, a useful method for quantitative determination of inactivated rabies virus antigen. J. biol. Stand., 9: 81- 89, 1981.

3. COX, J.H.; DIETZSCHOLD, B. \& SCHNEIDER, L.G. - Rabies virus glicoprotein. II. Biological and serological characterization. Infect. Immun., 16: 754-759, 1977.

4. DÍAZ, A.M. - Técnica de contrainmunoelectroforesis para el diagnóstico serológico de la rabia. Ramos Mejía, Centro Panamericano de Zoonosis OPS/OMS, 1985. (Monografía. No. 13).

5. DÍAZ, A.M.; NEBEL, A. \& MICELI, G.S. - A counterimmunoelectrophoresis technique for in vitro detection of antigens in rabies vaccines. In: THRAENHART, O.; KOPROWSKI, H.; BOGEL, K. \& SUREAU, P., ed. Progress in rabies control. England, Wells Medical, 1988. p. 305-310.

6. DÍAZ, A.M.; ROBIN, O.; GOROSTIAGA, M. \& MICELI, G. - Manual de producción y control de vacuna antirrábica producida en monocapa de células BHK. Versión Preliminar. Martinez, Buenos Aires, INPPAZ/OPS/OMS, 1995.

7. FERGUSON, M. \& SCHILD, G.C. - A single radial immuno-diffusion technique for the assay of rabies glycoprotein antigen: application for potency tests of vaccines against rabies. J. gen. Virol., 59: 197-201, 1982.

8. FERGUSON, M.; SEAGROATT, V. \& SCHILD, G.C. - A collaborative study on the use of single radial immuno-diffusion for the assay of rabies virus glycoprotein. J. biol. Stand., 12: 283-294, 1984.

9. FERGUSON, M.; SEAGROATT, V. \& SCHILD, G.C. - Single radial immunodiffusion assays for the standardization of the antigenic content of rabies vaccines. Develop. biol. Stand., 64: 81-86, 1986.

10. FERGUSON, M.; WACHMANN, B.; NEEDY, C.F. \& FITZGERALD, E.A. - The effect of strain differences on the assay of rabies virus glicoprotein by single radial immunodiffusion. J. biol. Stand., 15: 73-77, 1987.

11. FINNEY, D.J. - Statistical methods in biological assay. 2.ed. London, Charles Griffin, 1964. p. 99-138.
12. FITZGERALD, E.A. \& NEEDY, C.F. - Use of the single radial immunodiffusion test as a replacement for the NIH mouse potency test for rabies vaccine. Develop. biol. Stand., 64: 73-79, 1986.

13. HENDRIKSEN,C.; SPIESER, J.M.; AKKERMANS, A. et al. - Validation of alternative methods for the potency testing of vaccines. The report and Recomendation of European Centre for the Validation of Alternative Methods. Workshop 31. Italy, JRC Environment Institute, 1997.

14. MANCINI, G.; CARBONARA, A.O. \& HEREMANS, J.F. - Immunochemical quantitation of antigens by single radial immunodiffusion. Immunochemistry, 2: 235-254, 1965.

15. MAYNER, R. \& NEEDY, C.F. - Evaluation of the single radial-immunodiffusion assay for measuring the glycoprotein content of rabies vaccines. J. biol. Stand., 15: 1-10, 1987.

16. MiCELi, G.; TORRobA, J. \& DÍAZ, A.M. - Evaluación de la técnica de contrainmunoelectroforesis para determinar la potencia antigénica de las vacunas antirrábicas. Rev. Inst. Med. trop. S. Paulo, 35: 543-550, 1993.

17. SCHILD, G.C.; WOOD, J.M. \& NEWMAN, R.W. - A single-radial-immunodiffusion technique for the assay of influenza haemagglutinin antigen. Proposals for an assay method for the haemagglutinin content of influenza vaccines. Bull. Wld. Hlth. Org., 52: 223-231, 1975 .

18. SCHILD, G.C.; WOOD, J.M.; MINOR, P.D.; DANDAWATE, C.N. \& MAGRATH, D.I - Immunoassay of poliovirus antigens by single-radial-diffusion: development and characteristics of a sensitive autoradiographic zone site enhancement (ZE) technique. J. gen. Virol., 51: 157-170, 1980.

19. SCHNEIDER, L. - Aluminium phosphate method for rabies virus purification. In: KAPLAN, M.M. \& KOPROWSKI, H., ed. Laboratory techniques in rabies. Geneva, WHO, 1973. p. 179-181.

20. SELIGMAN Jr., E.B. - The NIH test for potency. In: KAPLAN, M.M. \& KOPROWSKI, H., ed. Laboratory techniques in rabies. Geneva, WHO, 1973. p. $279-286$.

21. SOKOL, F.; STANCEK, D. \& KOPROWSKI, H. - Structural proteins of rabies virus. J. Virol., 7: 241-249, 1971.

22. SPIEGEL, M.R. - Estadística. 2.ed. Madrid, Mc Graw-Hill/Interamericana de España, 1991. p. $375-410$.

23. THRAENHART, O. \& RAMAKRISHNAN, K. - Standardization of an enzyme immunoassay for the in vitro potency assay of inactivated culture rabies vaccines: determination of the rabies virus glycoprotein with polyclonal antisera. J. biol. Stand. 17: 291-309, 1989

24. WHO Expert Committee on Rabies. Eighth Report. Wld. Hlth. Org. techn. Rep. Ser., (824): 10-18, 1992

25. WILLIAMS, M.S.; MAYNER, R.E.; DANIEL, N.J. et al. - New developments in the measurement of the hemagglutinin content of influenza virus vaccines by singleradial-immunodiffusion. J. biol. Stand., 8: 289-296, 1980.

26. WOOD, J.M.; SCHILD, G.C.; NEWMAN, R.W. \& SEAGROATT, V. - An improved single-radial-immunodiffusion technique for the assay of influenza haemagglutinin antigen: application for potency determinations of inactivated whole virus and subunit vaccines. J. biol. Stand., 5: 237-247, 1977.

Received: 28 September 1999

Accepted: 20 October 1999 